\title{
Lietelannan kemiallinen fraktiointi: fosforin saostaminen
}

\author{
Liisa Pietola $^{1)}$, Sakari Alasuutari ${ }^{2}$ ja Reetta Palva ${ }^{2)}$ \\ ${ }^{1)}$ Kemira GrowHow Oyj, Tutkimuskeskus, 2 PL 2, FIN-02271 Espoo, liisa.pietola@kemira-growhow.com \\ ${ }^{2)}$ TTS tutkimus, PL 5, 05201 Rajamäki, sakari.alasuutari@tts.fi, reetta.palva@tts.fi
}

\section{Tiivistelmä}

Sian- tai naudanlietelanta sisältää liikaa fosforia käytettäväksi karjatilojen pelloille, joilla maan fosforipitoisuudet ovat korkeita. Ongelma rajoittaa tuotantoyksiköiden kokoa tai pakottaa viljelijät lisämaan hankintaan. Lannan fosfori pitäisi voida poistaa tai ratkaisevasti vähentää ennen pellolle ajoa.

Esiteltävä menetelmä perustuu saostusvalmisteen käyttöön lietesäiliössä ja sakan sedimentaatioon lietekaivon pohjalle ilman erityisiä koneinvestointeja. Ennen sedimentoitumisvaihetta saostusvalmiste sekoitetaan lietesäiliöön normaalilla lietteen sekoittajalla. Muutaman päivän tai viikon aikana saostusvalmiste sitoo fosforia nestejakeesta sedimentoituvaan kiintoainekseen (alite), jolloin lietteen yläosaan erottuu lähes fosforiton tai vain vähän fosforia sisältävä nestefraktio (ylite). Jakeiden ylite:alite tilavuussuhde on noin $1: 1$ tai jopa $2: 1$, niin kuin sianlannan lietelannan fraktioinnissa todettiin. Sedimentoituneen sakan kuiva-ainepitoisuus oli 15-18 \% ja ylitteen 1,5-2 \%. Lähes fosforivapaa ylite voidaan pumpata lietelannan levityskalustoon ja käyttää typpi-kalium- lannoitteena korkean fosforiluvun lohkoille. Fosforia sisältävä alite voidaan hyödyntää lannoitteena tilalla tai tilan ulkopuolella tai esimerkiksi energiantuotannossa.

Toisin kuin rauta- tai alumiinisulfaatilla saostettaessa, fosfori pysyy tässä menetelmässä viljelykasveille käyttökelpoisena kasvinravinteena: Menetelmässä vesiliukoinen fosfori saostetaan amorfisiksi kalsiumfosfaateiksi tai ammoniummagnesiumfosfaatiksi eli struviitiksi, joka on todettu erinomaiseksi lannoitteeksi. Saostuminen onnistuu, jos lietteen $\mathrm{pH}$ on yli 8. Koska varsinkin lietelannan $\mathrm{pH}$ on luontaisesti hapanta ja sisältää paljon $\mathrm{pH}$ :ta puskuroivaa kuiva-ainetta, lietelannan $\mathrm{pH}$ nostetaan saostusvalmisteen avulla lähelle 8. Laboratorio- ja tilakokeiden perusteella nestejakeen vesiliukoisen fosforin määrä laski alle kymmenesosaan paljon liukoista fosfaattifosforia sisältävällä sianlietelannalla (700 mg/kg:sta tasolle $10-20 \mathrm{mg} / \mathrm{kg}$ ). Tutkitun naudanlietelannan fosfori väheni noin viidennekseen (250 $\mathrm{mg} / \mathrm{kg}$ :sta tasolle $50 \mathrm{mg} / \mathrm{kg}$ ). Naudanlietelanta oli tässä tutkimuksessa haastavampi kuin sianlietelanta: Naudanlietelanta oli happamampaa ja kuiva-aine puskuroi pH:n nousua, mutta koe tehtiin myös viileämmissä olosuhteissa huhtikuussa kun sianlietelantakoe tehtiin toukokuun puolenvälin jälkeen.

Tutkimuksen mukaan saostusvalmisteen käyttömäärä vaihtelee 5-8 kg lietetonnia kohti. Helposti lietteeseen liukenevaa kalsiumsulfaattia ja magnesiumoksidia sisältävää saostusvalmistetta tarvitaan sitä enemmän mitä suurempi on lietteen kuiva-aine- ja/tai fosforipitoisuus. Menetelmän tilakäyttöä ja kannattavuutta naudanlietelannan käsittelyssä arvioidaan eri paperissa (Alasuutari ym. 2008: Lietelannan kemiallinen fraktiointi: käyttö ja kannattavuus). Tuotekehitystyö jatkuu varsinkin naudanlietelannan kohdalla.

Asiasanat

Fosfori, kalsiumsulfaatti, lietelanta, magnesiumoksidi, naudanlanta, sianlanta 


\section{Johdanto}

Sian- tai naudanlietelanta sisältää liikaa fosforia käytettäväksi karjatilojen pelloille: Viljelykasvien tarpeeseen nähden lietelanta sisältää ylen määrin fosforia suhteessa typpeen. Lietelannan N:P on 2:1 - 4:1 kun viljelykasvien ottama N:P on 4:1 - 9:1. Kun lantaa on levitetty kasvien typen tarpeen mukaisesti, osa lannan fosforista on jäänyt käyttämättä. Lopputuloksena karjatilojen peltojen fosforipitoisuudet ovat usein luokassa arveluttavan korkea, mikä rajoittaa lannan käyttöä näillä mailla. Jotta fosforimäärä pysyisi sallituissa rajoissa, eläintuotantoyksiköiden kokoa pitäisi supistaa. Vaihtoehtoisesti viljelijät ovat hankkineet lisämaata tai tehneet lannan vastaanottosopimuksia naapuritilojen kanssa korkean fosforipitoisuuden omaavan lietelannan levittämiseksi suuremmalle peltoalalle. Lannan kuljettaminen kauas vähemmän fosforia sisältäville peltolohkoille tai biokaasulaitoksiin aiheuttaa suuria kuljetuskustannuksia. Ongelmien ratkaisemiseksi lannan fosfori pitäisi voida poistaa tai ratkaisevasti vähentää ennen pellolle ajoa. Toisaalta arvokkaiden kasviravinteiden kierrättäminen viljelyssä ja pitäminen kasveille käyttökelpoisena on kestävän kehityksen mukainen ratkaisu.

Lieteongelmaan on haettu ratkaisua lannan mekaanisella separoinnilla: Lietelannan fosforipitoinen kiintoaines voidaan esimerkiksi erottaa nesteestä ruuvilla tai keskipakoisvoimalla seulojen avulla (Burton 2006, Balsari et al. 2006). Mekaaninen separointi vaatii kuitenkin lietteen pumppaamisen lietekaivosta erilliseen separaattoriin. Esimerkiksi Kemira Water'in menetelmässä tilalle viedään siirrettävä kontti tai tilalle asennetaan kiinteä lannankäsittely-yksikkö, jonka kautta lanta separoidaan ja jakeet palautetaan eri säiliöihin erilliseen jatkokäyttöön. Flokkulaatiota eli kiintoaineksen kasautumista edistetään polymeereillä, ja tarvittaessa fosforia voidaan saostaa rautavalmisteella (Kemira Water 2007). Akryyliamidien käyttöön perustuva polymeereillä flokkulointi lienee kuitenkin suuressa mittakaavassa ekolologisesti kyseenalaista; akryyliamidien hajoaminen maassa hidastuu kun pitoisuudet kasvavat. Samoin raudalla tai alumiinilla fosforin saostaminen rikastaa maaperään alumiini- ja rautafosfaatteja, joiden sidos ei aukea viljelymaan $\mathrm{pH}: \mathrm{ssa}(\mathrm{pH}>5)$.

Laboratorio-oloissa on osoitettu, että myös kalsiumsulfaatilla voidaan saostaa lietelannan fosforia. Heinonen-Tanski ym. (2000) raportoivat, että sianlietteen liukoisen fosforin pitoisuus laskee kalsiumfosfaatin saostumisen myötä, mikäli lanta ilmastoidaan. Lisäksi lietelannassa kiteytyy spontaanisti struviittia, $\mathrm{MgNH}_{4} \mathrm{PO}_{4} 6 \mathrm{H}_{2} \mathrm{O}$, mikäli lietteessä on riittävästi magnesiumia, ammoniumtyppeä ja fosforia sekä pH on lähellä 8,5 (Nelson ym. 2003). Yleensä lietelannan pH on 6,5-7 eikä tarvittavia alkuaineita struviitin muodostumiseksi ole oikeassa suhteessa. Siten esim. Schulze-Rettmer, $(2001,2007)$ kuvaamassa menetelmässä lietelanta-altaaseen lisättiin magnesiumoksidia (MgO) sekä fosforia struviitin saostamiseksi. Römer (2006) raportoi kvartsihiekassa tehdyn astiakokeen perusteella, että struviitti on erinomainen fosforilannoite ja samanveroinen kuin $\mathrm{Ca}\left(\mathrm{H}_{2} \mathrm{PO}_{4}\right)$ kun taas rautafosfaatin $\left(\mathrm{FePO}_{4}\right)$ fosfori ei ollut lainkaan kasvin käytettävissä.

Tämän tutkimuksen tavoitteena oli kehittää jokaisen tilan helposti omaksuttava menetelmä saostaa ja jakaa lietelannan fosfori kahteen eri jakeeseen ilman merkittäviä koneinvestointeja. Menetelmän kehittämisessä pyrittiin välttämään lannan siirtelyä ja kuljetusta käsittelyn aikana. Lisäksi lannan ravinteita pyrittiin saostamaan siten, ettei niitä sidottaisi pois ravinnekierrosta vaan lanta säilyisi kasvien ravinnelähteenä. Siten tuotekehityksessä ei käytetty rautaa tai alumiinia, vaan fosfori pyrittiin sitomaan kalsiumin ja magnesiumin avulla. Tavoitteena oli saada lannoituskäyttöön vähintään puolet lietelannan tilavuudesta siten, että lantajaetta voitaisiin levittää suoraan pellolle eikä levitettävän osuuden fosforipitoisuus olisi liian korkea.

\section{Aineisto ja menetelmät}

Fosforia saostettiin naudan- ja sianlietelannasta keväällä 2007 kahdella maatilalla lietesäiliöissä. Laboratoriossa ja konteissa tehtyjen esitutkimusten perusteella lietesäiliöihin lisättiin dihydraatti kalsiumsulfaattia $\left(\mathrm{CaSO}_{4} \cdot 2 \mathrm{H}_{2} \mathrm{O}\right)$ eli kipsiä, jota syntyy fosforihappoteollisuuden sivutuotteena (Kemira Growhow Oyj, Siilinjärven tehtaat). Kipsiä ja MgO:a sekoitettiin traktorikäyttöisellä ruuvilla lietteeseen. Maatilakokeiden aikana lietesäiliön pinnasta ja keskiosasta otettiin näytteitä, joista mitattiin $\mathrm{pH}$ ja vesiliukoinen fosfori. Näytteenoton yhteydessä mitattiin lietteen lämpötila ja redox-potentiaali (Marvet Junior 2000) lietekaivon eri syvyyksissä (naudanlietteellä 20, 50 ja $200 \mathrm{~cm}$ ). Lopuksi analysoitiin erikseen lietteen pintaosan eli ylitteen ja sakan eli alitteen kemialliset ominaisuudet (kokonais- ja vesiliukoinen $\mathrm{P}, \mathrm{K}$, kokonais- ja epäorgaaninen typpi, $\mathrm{pH}$ ). Kokonaistyppi mitattiin kuivapoltolla (LECO), $\mathrm{K}$ ja happoliukoinen P sekä epäorgaaninen typpi kolorimetrisesti autoanalysaattorilla (TRAACS) sekä 
vesiliukoinen fosfaatti-P ionikromatografisesti ja kolorimetrisesti molybdaattireaktiivisena. Saostusmenetelmää hiottiin vielä naudanlietelannan tilakokeen aikana, jolloin saostusvalmisteet sekoitettiin eri aikoina:

\section{Naudanlietelanta}

Lietealtaassa ( $2 \mathrm{~m} \times 3 \mathrm{~m}$ x $15 \mathrm{~m}$ ) oli 75 kuutiota naudanlietelantaa. Dihydraatti $\mathrm{CaSO}_{4}$ :a (kosteus $30 \%$ ) sekoitettiin $5 \mathrm{~g} \mathrm{~kg}^{-1}$ lietettä sekä viikon päästä lisättiin $\mathrm{MgO} 3 \mathrm{~g} \mathrm{~kg}^{-1}$. Koska naudanlietelannan $\mathrm{pH}$ ei

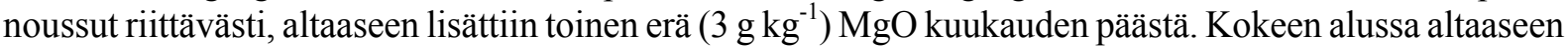
lisättiin myös 15 ppm kationista polymeeriä (K3450, Kemira Water), joka oli liuotettu 150 litraa vettä.

\section{Sianlietelanta}

Sianlietelannan pilottikokeessa saostus onnistui ilman erillisiä säätöjä ja sianlietelanta käsiteltiin vain kertaalleen: Metrin syvyiseen noin $65 \mathrm{~m}^{3}$ lietelantasäiliöön lisättiin $\mathrm{CaSO}_{4} \cdot 2 \mathrm{H}_{2} \mathrm{O} 4,5 \mathrm{~g} \mathrm{~kg}^{-1}$ sekä $\mathrm{MgO} 3 \mathrm{~g}$ $\mathrm{kg}^{-1}$. Lantasäiliöön lisättiin samanaikaisesti ennen sekoitusta kationista polymeeriä (15 ppm), joka oli liuotettu 1801 vettä.

\section{Tulokset ja tulosten tarkastelu}

Naudan lietelannan ravinnepitoisuudet $\left(\mathrm{g} \mathrm{kg}^{-1}\right)$ ennen käsittelyä olivat seuraavat: happoliukoinen kokonaisfosfori 0,35 ; vesiliukoinen fosfori 0,25 ; kokonaiskalium 0,24 ; vesiliukoinen kalium 0,24 ; kokonais typpi 2,0 ja ammoniumtyppi 1,3. Kuiva-aine oli 5,6 \%. Naudanlanta oli alkujaan sakean näköistä ja pintaan kertyi mikrobitoiminnan kaasunmuodostuksen johdosta kiintoainetta. Polymeeri ei erotellut kiintoaineista. Ensimmäinen $\mathrm{MgO}$-lisäys poisti sakkaa lietteen pinnalta. Lietteen $\mathrm{pH}$ kuitenkin pysyi alhaisena (Kuva 1), ja lietteeseen sekoitettiin toinen $\mathrm{MgO}$-erä, joka vasta nosti $\mathrm{pH}$ :n lähelle 8 . Toisen MgO-lisäyksen jälkeen 23.5.2007 naudanlietteen fosforipitoisuus laski selkeästi (Kuva 2). Niukasti fosforia sisältävän naudanlietteen ylitteen ja fosforia keräävän sakan tilavuussuhde oli noin 1:1. Kalium ja typpi eivät jakautuneet lannan eri jakeisiin kuten fosfori. Naudan lietelannan sakan kuiva-aine oli lopuksi keskimäärin $10 \%$ ja ylitteen $2,7 \%$.

Naudanlietelannan liukoisen fosforin sitominen anaerobeissa oloissa struviitiksi vaati $\mathrm{pH}: \mathrm{n}$ nousun. Kalsiumfosfaatin saostui oletettavasti amorfisena, mutta reaktio oli niin ikään mahdollinen vasta pH:n noustessa lähelle 8 . Kun pH saatiin nostettua kemiallisesti, fosforin sitominen $\mathrm{CaSO}_{4} \cdot 2 \mathrm{H}_{2} \mathrm{O}$ :lla ei vaatinut Heinonen-Tanski ym. (2001) raportoimaa $\mathrm{pH}$ :ta nostavaa ilmastusta. Allaskokeen aikana lietteen lämpötila vaihteli ja kevään edetessä lietteen lämpötila nousi yli 10-asteiseksi (Kuva 3). Lämpötilan nousu todennäköisesti edisti fosfaatin saostumista. Olosuhteet olivat syvemmissä kerroksissa anaerobiset.

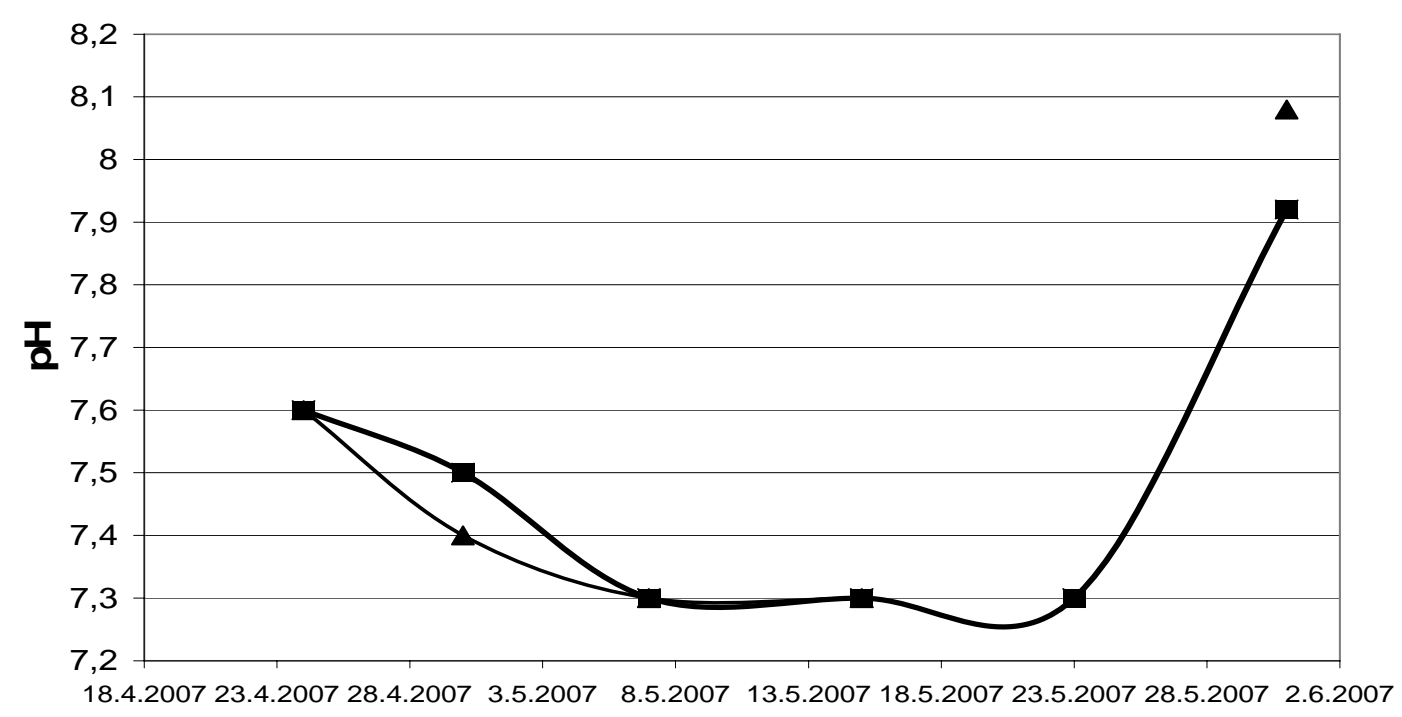

Kuva 1. Naudanlietelannan pH:n vaihtelu käsittelyn aikana $30 \mathrm{cm:n} \mathrm{(匹)} \mathrm{ja} 80 \mathrm{cm:n} \mathrm{( \Delta )} \mathrm{syvyydessä.}$ 


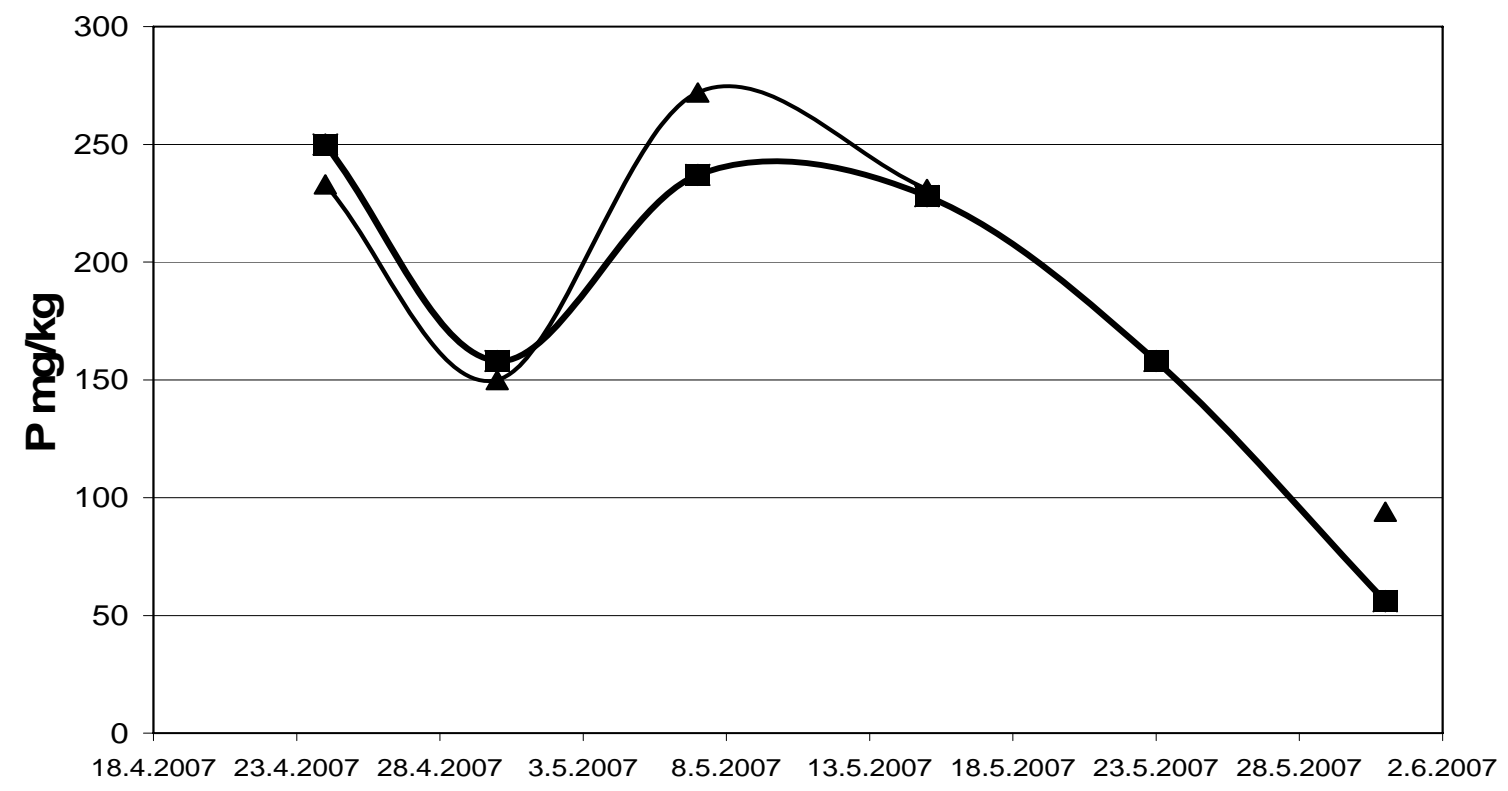

Kuva 2. Naudanlietelannan liukoisen fosforin vaihtelu käsittelyn aikana $30 \mathrm{~cm}: n$ (ロ) ja $80 \mathrm{~cm}: n$ ( $\boldsymbol{\Delta}$ ) syvyydessä.

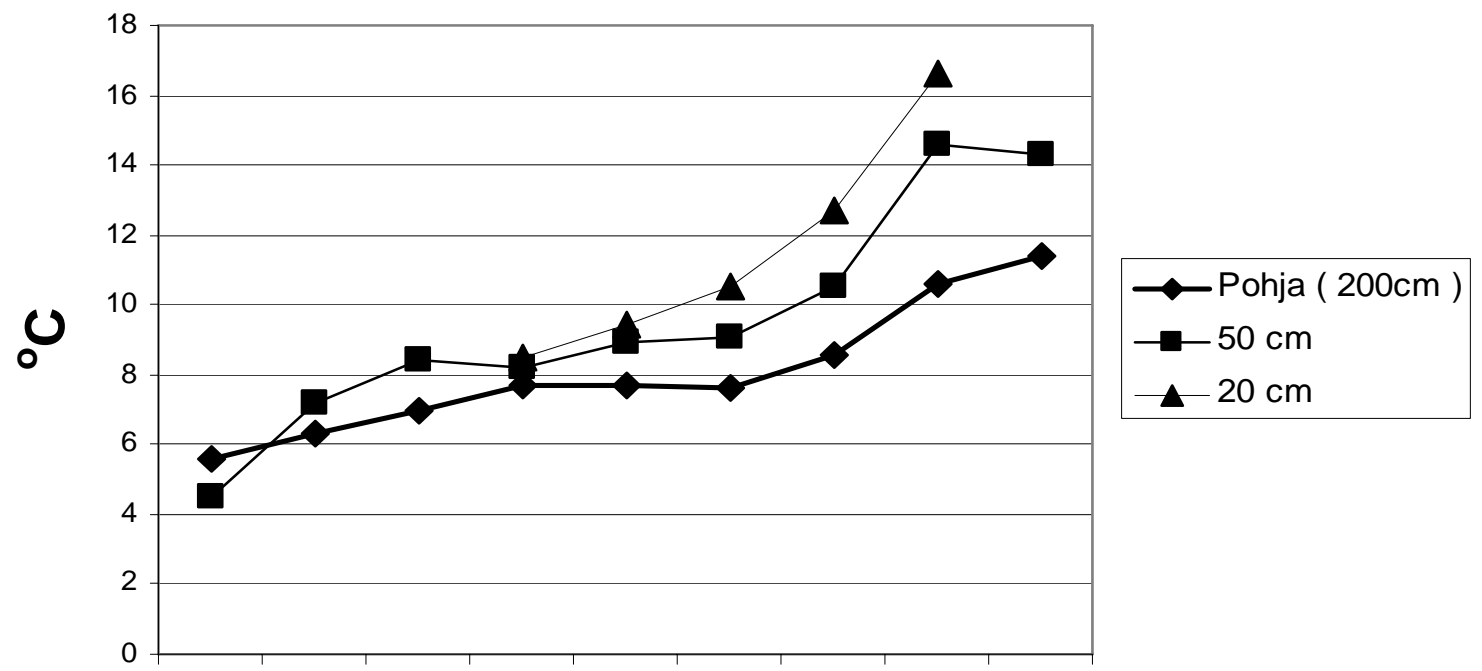

16.4. 23.4. 30.4. 7.5. 10.5. 15.5. 23.5. 31.5. 15.6 .

Kuva 3. Naudan lietelannan lämpötila lietesäiliön eri korkeuksissa.

Sianlietelannan tilakoe tehtiin touko-kesäkuussa 2007 fosforipitoisella lannalla (kokonaisfosfori $1,1 \mathrm{~g} \mathrm{~kg}^{-1}$; vesiliukoinen $0,7 \mathrm{~g} \mathrm{~kg}^{-1}$ ), jonka kuiva-ainepitoisuus oli 4,0\%. Sianlietelanta sisälsi kaliumia $1,7 \mathrm{~g} \mathrm{~kg}^{-1}$ (vesiliukoisena $1,0 \mathrm{~g} \mathrm{~kg}^{-1}$ ) ja typpeä noin $2,5 \mathrm{~g} \mathrm{~kg}^{-1}$, josta liukoista ammoniumtyppeä oli $1,9 \mathrm{~g} \mathrm{~kg}^{-1}$. Käsittelyn myötä kalium- ja typpi eivät juuri jakautuneet, mutta fosfori fraktioitui selkeästi: Vesiliukoinen fosfori laski jo seuraavana päivänä tasolle $50 \mathrm{mg} \mathrm{kg}^{-1}$ mittaussyvyydellä $0-10 \mathrm{~cm}$ ja oli sitä seuraavina päivinä $46-56 \mathrm{mg} \mathrm{kg}^{-1}$. Viiden päivän päästä $30 \mathrm{~cm}: n$ syvyydeltä otetun näytteen liukoisen fosforin pitoisuus oli $47 \mathrm{mg} \mathrm{kg}^{-1}$ (kokonaisfosfori $87 \mathrm{mg} \mathrm{kg}^{-1}$ ) (Kuva 4). 


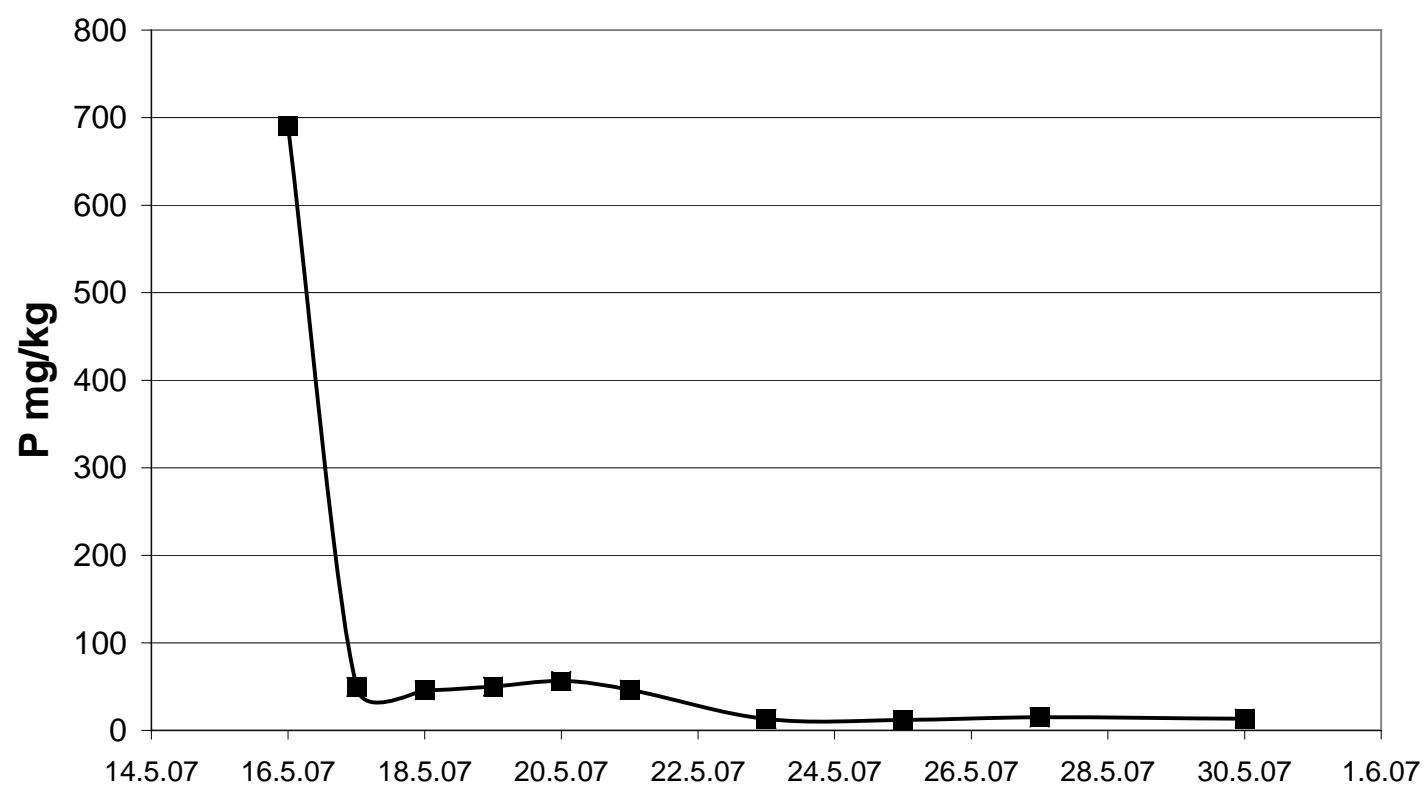

Kuva 4. Sianlietelannan liukoisen ortofosforin pitoisuus kokeen alussa ja käsittelyä seuraavina päivinä.

Sianlietelannalla fosforipitoisuuden lasku onnistui, koska pH nousi välittömästi yli 8 (Kuva 5). Erottuva ylite todettiin edustavan 2/3 lietteen kokonaistilavuudesta kokeen lopussa. Polymeeri ei toiminut tälläkään kerralla, sillä kationiset polymeerit todennäköisesti menettivät tehonsa neutraaleissa oloissa ja etenkin fosfaatin saostumiselle välttämättömissä alkaleissa oloissa. Alitteen kuiva-aine oli lopussa $18 \%$ ja ylitteen $1,7 \%$.

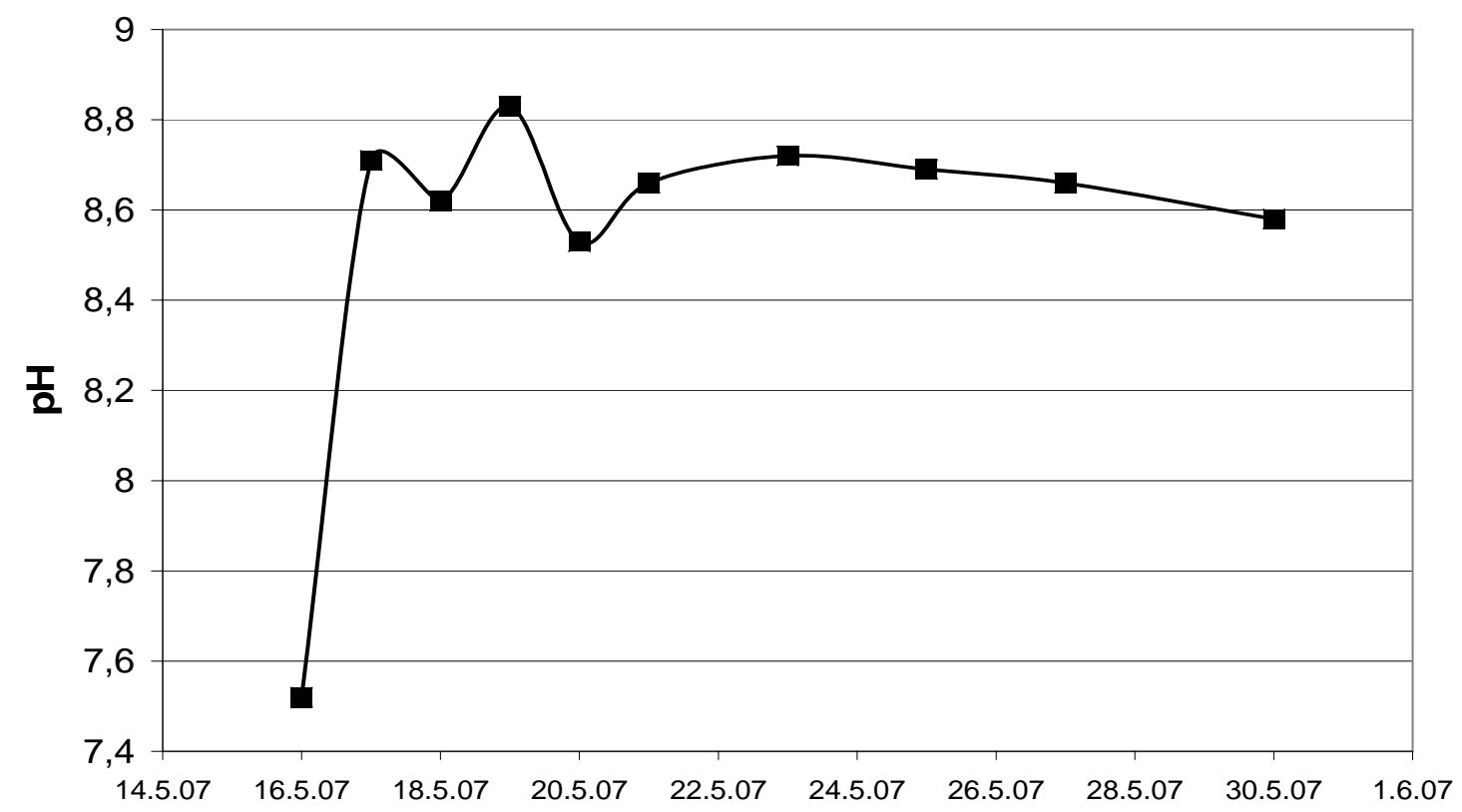

Kuva 5. Sianlietelannan pH kokeen alussa ja käsittelyä seuraavina päivinä. 
Tutkimusten mukaan saostusvalmisteen käyttömäärä vaihtelee 5-8 kg lietetonnia kohti. Helposti lietteeseen liukenevaa kalsiumsulfaattia ja magnesiumoksidia sisältävää saostusvalmistetta tarvitaan sitä enemmän mitä suurempi on lietteen kuiva-aine- ja/tai fosforipitoisuus. Tässä tutkimuksessa sianlietelannan fosforin fraktiointi onnistui paremmin kuin viileämmissä oloissa tehdyn naudanlietelannan käsittelyn. Tuotekehitystä jatketaan etenkin naudanlietelannan käsittelyssä.

\section{Johtopäätökset}

Lietelannan vesiliukoisen fosforin määrää voidaan merkittävästi alentaa ilman lannan erillistä kuljetusta separaattoriin. Lannan fraktiointia ja fosforin erottumista voidaan tehostaa lietesäiliössä lisäämällä lantaan kalsium- ja magnesiumyhdisteitä sisältävää saostusvalmistetta, joka nostaa lietteen pH:n lähelle 8 . Oletettavasti fosforin saostuminen tapahtuu samanaikaisesti sekä aerobisesti, jolloin muodostuu lähinnä amorfista kalsiumfosfaattia, että anaerobisesti, jolloin muodostuu struviittia. Saostuminen useammaksi yhdisteeksi riippuen paikasta ja olosuhteista lietesäiliön sisällä aikaansaa tehokkaan liukoisen fosforin saostumisen ja pintalietteen selkiytymisen. Menetelmällä käsitelty lietelannan nesteosa voidaan käsittelyn jälkeen pumpata takaisin maatilan pelloille lannoitteeksi, joka sisältää typpeä ja kaliumia, mutta vain vähän tai ei ollenkaan fosforia. Fosforipitoinen sakka voidaan käyttää peltolannoitteena tai raaka-aineena biokaasutuotannossa.

\section{Kirjallisuus}

Balsari, P., Santoro, E., Dinuccio, E., Gioelli, F. 2006. Assessment of the performances of different mechanicaal solid-liquid separators for pig and cattle slurries. $12^{\text {th }}$ Ramiran International conference. Vol. II. DIAS report 122: 157-159.

Burton, C. H. 2006. The contribution of separation technologies to the management of livestock manure. $12^{\text {th }}$ Ramian International conference. DIAS report 122: 43-48.

Heinonen-Tanski, H. Hirvonen, A. \& Tanni, K. 2000. Phosphorous loads caused by slurry fertilization to waters may be reduced by slurry aeration and waste gypsum powder, Pro Terra 4, 106-107

Kemira Water. 2007. http://www.kemira-miljoe.dk/gylleseparation/eng/index.asp

Römer, W. 2006. Vergleichende Untersucung der Phosphatverfügbarkeit von Produkten des P-Recyclings und bekannter Phosphatdünger. J. Plant Nutr. Soil Sci. 169: 826-832

Nelson, N.O., Mikkelsen, R.L. \& Hesterberg, D. L. 2003. Struvite precipitation in anaerobic swine lagoon liquid: effect of $\mathrm{pH}$ and $\mathrm{Mg}: \mathrm{P}$ ratio and determination of rate constant. Bioresource Technology 89: 229-236.

Schulze-Rettmer, R., von Fircks, R. \& Simbach, B, 2001. MAP precipitation - pilot plant investigation in Germany. Environmental Technology.

Schultze-Rettmer,R., Metzen, P., Alfter, P. \& Simbach, P. 2007. http://www.nhm.ac.uk/researchcuration/projects/phosphate-recovery/Nordwijkerhout/Schulze.doc 